\title{
Comparative Studies of the Impacts of Freshwater, Cultivated and Preserved Tiger Shrimps on Consumers' Health
}

\author{
Isibor Patrick Omoregie ${ }^{1^{*}}$, Izegaegbe Joshua Idowu ${ }^{2}$ \\ Igbinovia Joan Osahenrunmwen ${ }^{3}$, Obafemi Dorcas Yemisi ${ }^{1}$ \\ and Oluowo Elohor Freeman ${ }^{4}$
}

${ }^{1}$ Department of Biological Sciences, College of Science and Technology, Covenant University, Ota, Ogun State, Nigeria.

${ }^{2}$ Department of Zoology, University of Zululand, Richards Bay, South Africa. ${ }^{3}$ Department of Nursing, School of Basic Medical Sciences, Obafemi Awolowo University, Ife, Nigeria. ${ }^{4}$ Department of Animal and Environmental Biology, University of Benin, Benin City, Nigeria.

Authors' contributions

This work was carried out in collaboration between all authors. Author IPO designed the study, wrote the protocol and wrote the first draft of the manuscript. Author IJO carried out all medical related procedures and analysis. Author IJI managed the analyses of the study. Authors IJI, ODY and OEF managed the statistical analysis and the literature searches. All authors read and approved the final manuscript.

\section{Article Information}

DOI: $10.9734 / A R R B / 2018 / 38069$ Editor(s):

(1) Nema Abdelhameed Mohamed, Department of Zoology, Alexandria University, Alexandria, Egypt. (2) George Perry, Dean and Professor of Biology, University of Texas at San Antonio, USA.

Reviewers:

(1) María del Carmen Bermúdez Almada, Mexico. (2) Suneeta Kumari, Maulana Azad National Institute of Technology, India (3) Edebi N. Vaikosen, Niger Delta University, Nigeria. Complete Peer review History: http://www.sciencedomain.org/review-history/22956

Original Research Article

Received $29^{\text {th }}$ October 2017 Accepted $10^{\text {th }}$ January 2018 Published $31^{\text {st }}$ January 2018

\section{ABSTRACT}

Aim: The study was aimed at comparing the levels of heavy metals in Tiger shrimps- Penaeus monodon from different source categories, to ascertain the impacts of the selected heavy metals on the consumers' health.

Hypothesis: Heavy metals in blood serum of shrimp consumers were accumulated solely from the shrimps.

*Corresponding author: E-mail: patrick.isibor@covenantuniversity.edu.ng, patrickisibor007@gmail.com; 
Methodology: Tiger shrimps obtained from Ekpan Creek, Shrimp industry and shrimp farm were tested for metals (iron, manganese, nickel, and lead) concentrations using a Perkin Elmer 3110 model Atomic Absorption Spectrophotometer (AAS). Blood samples of respondents were analyzed for the levels of iron, manganese, nickel and lead using Inductively Coupled Plasma MassSpectrometer (ICP-MS). Analysis of Variance (ANOVA) was used to test for the significant differences in the heavy metals in the shrimps and consumers' blood samples at probability level of 0.05. Duncan Multiple Range (DMR) test was used to identify the source of variance using SPSS version 19.1. Health Risk Indices of heavy metals were noted as significant from 1 and above and insignificant at below 1.

Results: The shrimps exhibited different trends of heavy metals according to their sources. Results showed that the safety in consumption of the shrimps was is in the order of cultivate (pond) shrimps $>$ freshwater shrimps > preserved shrimps. Shrimp consumption had corresponding impacts on the health of the consumers. Processed shrimps should be properly examined for fitness of consumption prior to marketing, while chemicals such as sodium bisulfate, tripolyphosphate should be discouraged.

Conclusion: Metallic construction materials should be discouraged and stringent water quality monitoring is recommended in Tiger shrimp aquaculture while incorporating adoption of environment friendly agricultural practices. Perturbed aquatic environments such as Ekpan Creek require protection from anthropogenic activities and impactful remediation process with a view to protecting the Tiger shrimps and other aquatic biota.

Keywords: Freshwater shrimp; cultivated shrimp; preserved shrimp; heavy metals; blood serum; health risk index.

\section{INTRODUCTION}

Shrimps are highly demanded delicacy globally, due to their nutritional values [1]. They contain low fat, high protein, vitamin $\mathrm{B}_{12}$ and are also selenium-rich; thus enhances immunity, thyroid function and reproductory system [2,3]. There are two types of shrimp farms, namely coastal and inland shrimp farms. The disadvantage of coastal practices is due to the fact that they exchange water directly with the ocean hence the pond is prone to shrimp escape. Coastal farms also cause destruction of mangrove swamps hence impacting habitats of fish, shellfish and aquatic birds. Although inland ponds reduce the potentials for escape, both practices face the challenge of water pollution due to contaminations from feces and waste foods from the ponds.

Shrimp farmers use ponds that become ever more crowded and dirty as the animals grow. The drive to maximize space for profit by producing more shrimps in less space has resulted in some farmers adding like commercialgrade fungicides and pesticides to the water in order to abate illness under such crowded conditions. There have been reports of farmers treating pond water with banned antibiotics. After capture, shrimps are stored in freezers with salt, water and an additive called sodium bisulfite which is an industrial bleaching agent. The essence of sodium bisulfite is that it slows down decomposition and abates the process of melanosis, a condition that makes the harvested shrimp to blacken over a short time. Another preservative is sodium tripolyphosphate (STP), a dehydrating agent that gives the shrimps the firmness to protect it during handling throughout the stages from producers to consumers.

Indiscriminate discharge of refuse, industrial effluents, petroleum wastes and crude oil spills replete with heavy metals into nearby aquatic systems have impacts on the biota component and may eventually impact the health of the populace that consume the finfish and shellfish harvested from such waterbodies. Contamination of heavy metals in the aquatic environment has attracted global attention owing to its abundance, persistence and environmental toxicity. The increasing pollution by heavy metals has a significant adverse health effects for invertebrates, fish, and humans. Farmed fishes as well as aquacultures heavily rely on formulated feed and few of the commercial feed producers failed to meet up with standards for the requirement of fish and the source of raw material for the production of the feeds tends to be contaminated with heavy metals and others $[4,5]$. The metal pollution of aquatic ecosystems is increasing due to the effects of urbanization and industrialization [6]. Toxic heavy metals are unrelenting environmental contaminants because they cannot be despoiled or destroyed [7] and 
comprise a significant portion of the problem as these metals known for their bioaccumulation and bio-magnification, which cause various health hazards to human [8]. Generally, culture fish bio-accumulate chemicals as well as heavy metals directly from polluted water by diffusion through gill and skin or they ingest with food [9]. The mechanism is by incorporation of heavy metals from anthropogenic perturbations into the aquatic food; thereby biomagnifying up the pyramid of biomasses through alimentation [8]. Variability in water and sediment properties is a function of a number of factors which have been enormously reported in previous studies. Generally, these factors can be categorized as authoctonous and allothonous factors working in tandem. Tukura et al. [10] attributed variation of physico-chemical properties of water and sediment of Mada River, Nasarawa State, Nigeria to seasonal variation.

The water matrix of an aquatic ecosystem is the first receptor of the contaminants released from anthropogenic activities. The sediment then serves as repository to the contaminants [11]. However, the rate of deposition of these contaminants is a function of their sorption capacities; which vary among contaminants. Ogbeibu et al. [12] pointed out that manganese, zinc, copper, cadmium, lead and total hydrocarbons had very high sorption capacities from water into the sediment of Ikpoba River. Furthermore, the contaminants journey from these environmental matrices into the tissues of biota where they are stored indefinitely. Froese et al. [13] reported bioaccumulation of polychlorinated biphenyls from sediments to aquatic insects in Saginaw Bay, Michigan, USA. Davies et al. [14] reported accumulation of heavy metals in tissues of Tympanotomus var radula from sediment of Elechi Creek, Nigeria. Akan et al. [15] attributed accumulation of metals in the gills, liver, stomach, kidney, bones and flesh tissues of Tilapia zilli, Clarias anguillaris, Synodentis budgetti and Oreochronmis niloticus from River Benue to the concentrations in the ambience. Isibor et al. [11] attributed impermissible levels of trace metals in Clarias gariepinus of Osse River, Edo State, Nigeria to high levels observed in the water and sediment.

The study aimed at comparing the levels of heavy metals in Tiger shrimps- Penaeus monodon (Fabricius, 1798) from different source categories, with a view to ascertaining the impacts on consumers' health.

\section{MATERIALS AND METHODS}

\subsection{Materials}

The apparatuses used include Perkin Elmer 3110 model Atomic Absorption Spectrophotometer (ASS), Thermo (Bremen, Germany) X Series 2 Inductively Coupled Plasma Mass Spectrometer (ICP-MS), concentric glass nebulizer, peltier-cooled glass spray chamber, Silica flasks, volumetric flasks, Whatman filter paper 42, Bunsen burner, and glass plate. The reagents include $\mathrm{HNO}_{3}: \mathrm{HClO}_{4}$

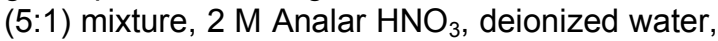
Analar grade metal salt, non-stabilized $30 \%$ hydrogen peroxide $\left(\mathrm{H}_{2} \mathrm{O}_{2}\right)$ solution and distilled water. Shrimp samples captured from the Creek using woven cylindrical non-return valve traps, baskets and scoop nets, coconut, cassava and earthworm baits.

\subsection{Methods}

\subsubsection{Experimental design}

The experiment was designed to analyze the concentrations of $\mathrm{Fe}, \mathrm{Mn}, \mathrm{Zn}, \mathrm{Cu}, \mathrm{Pb}, \mathrm{Cd}$, and $\mathrm{Ni}$ in 90 human blood samples from 3 groups (30 replicates per group) namely pond shrimp consumers, freshwater shrimp consumers and preserved shrimp consumers.

\subsubsection{Research hypothesis}

1. Each group of consumers depended solely on the specific shrimp category for their animal protein requirement.

2. The shrimps are solely the source of heavy metals in the blood of the subjects.

3. All human subjects have fed on same quantity of shrimp for at least 2 years.

4. Metal exposure of the shrimp groups is basically dependent on the respective operation techniques required for each group.

Blood samples were collected early in the morning (at 8:00 hrs) before breakfast so as to minimize alterations as a result of exposure of human subjects to metals through other routes than oral and to ascertain proper digestion of food consumed the previous day during night rest. Sampling periodicity was at interval of 2 weeks and 5 times fortnightly in order to minimize possible error due to alterations in diet and health status $[16,17]$. 


\subsubsection{Sample collection}

\subsubsection{Shrimps}

Samples of Tiger shrimps- Penaeus monodon were obtained from Ekpan Creek using local fishing gears such as woven cylindrical nonreturn valve traps, baskets and scoop nets; in conjunction with coconut, cassava and earthworm baits. Other categories were obtained from a commercial pond, and a sea food store. The shrimps in the pond were fed with a mixture of natural food items such as coconuts, worms and supplemented with commercial shrimp feed. Shrimps (Penaeus monodon) were caught in the local coastal waters and were kept alive in water tanks on board. Immediately after arrival on board the boat, they were sorted by size (standard length: $12-15 \mathrm{~cm}$ and weight: $24-32 \mathrm{~g}$ ) and kept alive in aerated tanks during the transportation to the laboratory within half an hour. The shrimps were then chilled to death by crushed ice in the laboratory. Anthropogenic activities such as oil exploration and exploitation activities were observed around the Creek. Some preservatives were used to conserve the shrimp stock obtained from the frozen food store. Shrimps obtained from the natural environment (Ekpan Creek), a shrimp farm (pond), and seafood store (preserved stock) were identified using identification manual prepared by Chan [18] and sorted according to size and weight. Thirty (30) shrimp individuals within the range of $12-15 \mathrm{~cm}$ (standard length) and 24- $32 \mathrm{~g}$ (weight) from each source were grouped into three categories, preserved in ice coolers and labelled as freshwater, cultivated and preserved shrimps. They were transported immediately to the laboratory for identification and further analysis.

\subsubsection{Consumers' blood samples}

A total 90 human volunteers above 18 years were recruited into the research with their informed consents. All precautions provided by World Medical Association [19] were duly adopted in sampling the blood of respondents. Only non-smokers and those who are medically fit were recruited into the study. Their general health status was also verified through routine inquiries based on the fact that the health status of respondents is a function of the concentrations of metals and their blood [16,17]. $3 \mathrm{~mL}$ of whole venous blood samples of 30 donors (15 males and 15 females) from each group was collected using sterilized syringes and placed in EDTA containers with lid, preserved with lithium heparin anti-coagulant. Each sterile syringe and needle was properly disposed of after use on each respondent.

\subsubsection{Sample preparation}

\subsubsection{Shrimps}

Wet weight shrimp tissue $(10 \mathrm{~g})$ was placed in silica flasks covered with a glass plate, $20 \mathrm{~mL}$ of $\mathrm{HNO}_{3}: \mathrm{HClO}_{4} \quad(5: 1)$ digester was added. Digestion process was carried out by heating the mixture at $105^{\circ} \mathrm{C}$ for about 24 hours according to Turkmen [20]. The extract was made up to 25 $\mathrm{mL}$ with $2 \mathrm{M}$ Analar $\mathrm{HNO}_{3}$ and diluted with deionized water. For quality assurance, reagent blanks were processed simultaneously in triplicates. Each residue was filtered into volumetric flasks with the aid of a Whatman filter paper.

\subsubsection{Consumers' blood samples}

Prior to digestion, all blood samples were vortexed thoroughly to ascertain homogeneity. Reagent blanks were prepared by adding deionized water in place of the samples to monitor background concentrations of all analytes. $1 \mathrm{~mL}$ of $2 \mathrm{M}$ Analar grade $\mathrm{HNO}_{3}$ was added to each blood sample and was allowed to react for 30 minutes. Thereafter, $750 \mu \mathrm{L}$ of nonstabilized $30 \%$ hydrogen peroxide $\left(\mathrm{H}_{2} \mathrm{O}_{2}\right)$ solution was added to each sample. After addition of all reagents, the tubes were sealed with lids and digested for 4 hours using a microwave machine (CEM, Matthews, NC). Samples were then removed from the microwave and allowed to cool. Samples were then stored in a refrigerator at $8^{\circ} \mathrm{C}$ until analysis.

\subsubsection{Sample analysis}

\subsubsection{Shrimps}

The solution prepared from shrimp sample was tested for metals (iron, manganese, nickel, and lead) concentrations using a Perkin Elmer 3110 model Atomic Absorption Spectrophotometer (ASS) and recorded in $\mathrm{Mg} / \mathrm{Kg}$; wet weights [21]. To determine metal concentration, the ASS was calibrated for each metal by dissolving $1 \mathrm{gram}$ Analar grade metal salt in $1 \mathrm{~L}$ of distilled water. Standard and corresponding blanks were run with each set of experimental digest. The detection limits of iron $(0.5 \mu \mathrm{g} / \mathrm{g})$, manganese $(0.5 \mu \mathrm{g} / \mathrm{g})$, nickel $(0.05 \mu \mathrm{g} / \mathrm{g})$, and lead (0.03 $\mu \mathrm{g} / \mathrm{g}$ ) were carefully observed. 
The actual concentration of metal was calculated thus:

Actual concentration of metal ( $\mathrm{Mg} / \mathrm{Kg}$ wet weight) $=\mathrm{RD} \times$ Dilution factor [22].

Where $R D=A S S$ reading of digest

$$
\text { Dilution factor }=\frac{\text { Volume of digest }}{\text { Weight of digest }}
$$

\subsubsection{Consumers' blood samples}

Blood samples were then analyzed for trace metals using the Thermo (Bremen, Germany) $X$ Series 2 Inductively Coupled Plasma Mass Spectrometer (ICP-MS) equipped with a concentric glass nebulizer and peltier-cooled glass spray chamber. Trace metal calibration standards for ICP-MS analysis were prepared using $\mathrm{Fe}, \mathrm{Mn}, \mathrm{Zn}, \mathrm{Cu}, \mathrm{Pb}, \mathrm{Cd}$, and $\mathrm{Ni}$ standards. Two sets of calibration standards were prepared for metals that were anticipated to be in low concentrations (such as $\mathrm{Pb}, \mathrm{Cd}, \mathrm{Ni}$, and $\mathrm{Mn}$ ) and high concentrations (such as $\mathrm{Fe}, \mathrm{Zn}$, and $\mathrm{Cu}$ ). Samples were analyzed without dilution in the original storage containers to minimize the possibility of contamination. For the calibration, standards back-calculated concentrations were ensured to be within $\pm 15 \%$ of the nominal concentration $( \pm 25 \%$ of the nominal concentration for the lowest concentration standard). Quality control checks were done to ascertain that concentrations for all metals were found to be within $\pm 15 \%$ of the nominal concentration.

\subsection{Statistical Analysis}

Descriptive statistics such as the mean, range and standard error were used in assessing the significant differences in the heavy metals in blood and shrimp samples using ANOVA ( $P$ < 0.05). Duncan Multiple Range (DMR) test was used to identify the source of variance using SPSS version 19.1. Mean of data generated were compared with mean concentrations of the heavy metals in the shrimps. Health risk indices of the metals in the respondents were assessed.

\subsection{Health Risk Assessment}

Health risk assessment is the knowledge of the quantitative risk each contaminant poses to the health of the consumers of the fishes. Health risk indices (HRI) of the heavy metals above one (1) was presented as significant while HRI below 1 was insignificant.

Health Risk Index was calculated thus;

Health Risk Index $(\mathrm{HRI})=$

Daily Intake of Metal (DIM)

Reference Oral Dose (ROD)

While Daily intake of metals (DIM) $=$

\section{$\underline{\text { M X CF X Daily intake of fish }}$ Average body weight}

Where $M$ was the metal concentration in fish tissue $(\mathrm{Mg} / \mathrm{Kg})$, CF is Conversion factor $=0.085$. $60 \mathrm{~kg}$ was adopted as the average body weight of the consumers of the fish. Daily intake of fish was estimated as the fish consumption rate in Nigeria $=48 \mathrm{~g} /$ person/day [23].

\section{RESULTS AND DISCUSSION}

All tested metals ( $\mathrm{Fe}, \mathrm{Mn}, \mathrm{Zn}, \mathrm{Cu}, \mathrm{Pb}, \mathrm{Cd}$, and $\mathrm{Ni})$ were detected in all the analyzed categories of shrimp samples. However, the different categories of shrimps had distinguished metal distributions.

\subsection{Distribution of Metal Contaminants in Shrimps}

The trend of metal contaminants in freshwater, cultivated and preserved shrimps were; $\mathrm{Mn}>\mathrm{Ni}$ $>\mathrm{Zn}>\mathrm{Fe}>\mathrm{Pb}>\mathrm{Cd}, \mathrm{Fe}>\mathrm{Zn}>\mathrm{Mn}>\mathrm{Ni}>\mathrm{Pb}>$ $\mathrm{Cd}$ and $\mathrm{Zn}>\mathrm{Mn}>\mathrm{Ni}>\mathrm{Cd}>\mathrm{Fe}>\mathrm{Pb}$ respectively. The trend of metal contamination in the cultivated Tiger shrimps of the current similar was similar to the trend ( $\mathrm{Fe}>\mathrm{Zn}>\mathrm{Mn}>\mathrm{As}>\mathrm{Co}$ ) observed in shrimps (Penaeus semisulcatus) captured from Persian Gulf by Heidarieh et al. [24]. The remaining part of the trend observed in the cultivated Tiger shrimps was similar to the trend observed by Das et al. [25] in Clarias gariepinus which was: $\mathrm{Cr}>\mathrm{Cu}>\mathrm{Ni}>\mathrm{Pb}>\mathrm{Cd}$ in cultivated Claria gariepinus. The similarities in the accumulation trend might be due exposure of the organisms to the observed heavy metals in the different environments.

However, the trend of metals in the three categories of Tiger shrimps in the current study is at variance with the trend $(\mathrm{Fe}>\mathrm{Cu}>\mathrm{TPH}>\mathrm{V}>$ $\mathrm{Cd}>\mathrm{Pb}>\mathrm{Mn}$ ) observed in Palaemonid shrimp: Macrobrachion vollenhovenii of Osse River in Nigeria by Isibor and Oluowo [24]. Differences 
observed between the current study and the previous can be attributed to variation in the levels of exposure, species of the shrimps [15], feeding habits etc. $[27,28,29,30]$.

\subsection{Concentrations of Metals in Different Categories of Shrimps}

Concentrations of iron (Fig. 1), and manganese (Fig. 2) among the compared shrimp samples were in the order of preserved shrimp > freshwater shrimp > FAO > pond shrimp. The concentrations of iron and manganese in the preserved shrimp and freshwater shrimp were significantly higher than the limits set by the Food and Agricultural Organization (FAO). High concentration of these metals observed in the preserved shrimp can be attributed to the chemicals used in the process of preservation. The unacceptable limits observed in the freshwater shrimps may be due to the complimentary impact of anthropogenic activities on Ekpan Creek, coupled with resultant effects of the intrinsic and extrinsic factors influencing the ingestion, metabolism and depuration of the metal in the shrimps. Bioaccumulation of iron and manganese from the wild, prior to capture, coupled with preservation techniques might have concertedly contributed to the outstandingly high concentration detected in the preserved shrimps. Although the level of iron observed in the cultivated shrimp was fairly lower than the regulatory limit, the concentration might rise above the recommended limit over time if the source of the contamination is not prevented. Iron contamination of ponds may ensue from the materials used in the pond construction. Metal tanks for examples, are prone to corrosion which could be enhanced by the water in the tank. Impermissible dietary levels of iron observed in the preserved and freshwater shrimps may elicit many implications in the consumers such as multi-system organ failures, coma, convulsion and ultimately death in shrimp and human $[31,32]$.

Only the concentration of manganese in the tissues of the pond shrimp was lower than the standard regulatory limit. Although manganese is an essential element in enzymes such as arginase, pyruvate carboxylase, and manganese-superoxide dismutase. Despite the vital biological roles manganese plays, excess concentration may cause serious health implications such as permanent neurological damage, insomnia, poor cognitive performances etc. [33].

The concentrations of zinc detected in all the shrimp categories were higher than the established FAO regulatory limit i.e. preserved shrimp > freshwater shrimp > pond shrimp (Fig. 3). Zinc is ubiquitous within cells in contrast to iron, which is contained in defined cellular components and has defined physiological roles. The biological role of zinc can be categorized into three functional classes namely, catalytic, structural and regulatory functions [34]. Although zinc is essential for the epidermal, gastrointestinal, central nervous, immune, skeletal and reproductive systems of vertebrates. Exposure of humans to high concentration of zinc over a long period of time may result in health challenges such as stomach cramps,

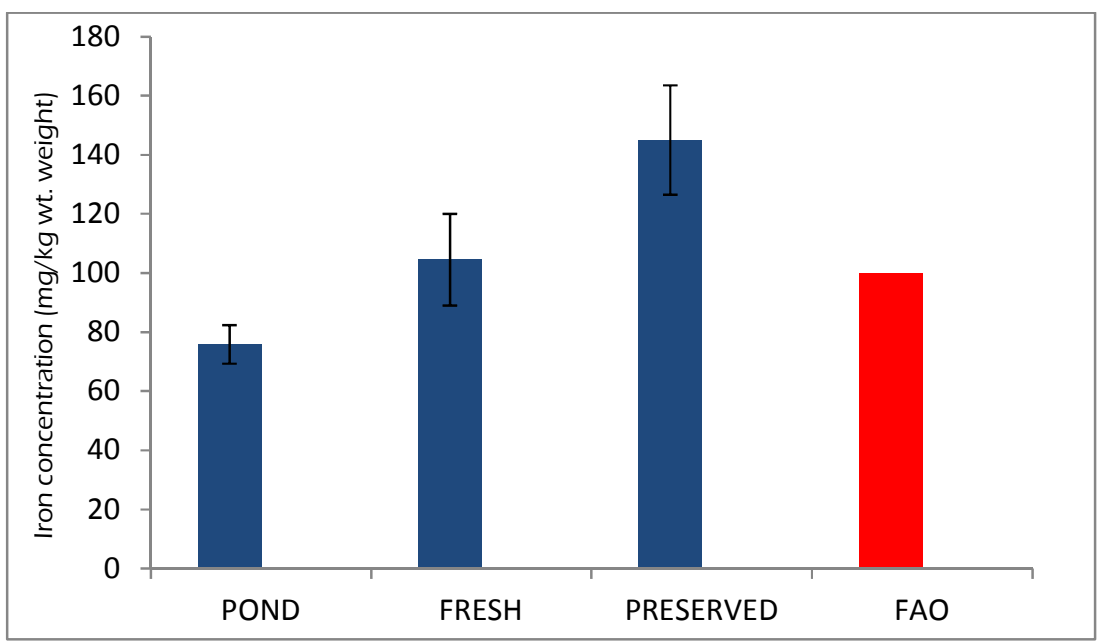

Fig. 1. Concentrations of iron in different shrimp categories $N=30, F A O$ limit $=100 \mathrm{Mg} / \mathrm{Kg}$ wt. weight [22] 


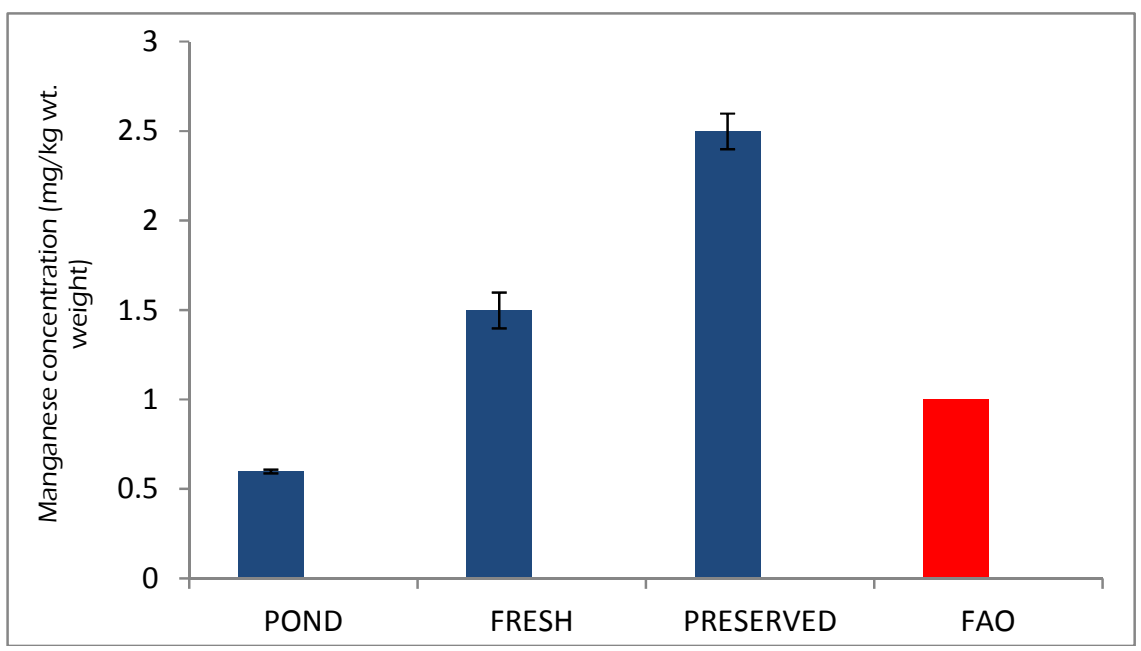

Fig. 2. Concentrations of manganese in different shrimp categories $N=30, F A O$ limit= $1 \mathrm{Mg} / \mathrm{Kg}$ wt. weight [22]

nausea, vomiting, and in extreme cases more devastating consequences such as anemia, damage to the pancreas, and decreased levels of high density lipoproteins (HDL) cholesterol may occur [35]. Toxicity of zinc has also been demonstrated in rats, rabbits and shrimps. High concentrations of zinc observed in the tissues of the cultivated shrimp can be attributed to the components of the shrimp feed. This is based on the fact that research findings have demonstrated a commensurate response of vertebrates to manipulation of dietary zinc [36]. Homeostasis of zinc is therefore essential for animals and humans. Homeostasis is mediated in vertebrates by adjustments in total zinc absorption and endogenous intestinal excretion
[37]. Entire zinc burden in vertebrates is lost through gastrointestinal tract and losses through skin, hair and sweat $[36,38]$. Findings have shown that iron and zinc exhibit antagonistic interaction i.e. the higher the accumulation of one the less the accumulation of the other i.e. high doses of inorganic iron decreased zinc uptake as measured by changes in plasma zinc after an oral dose [38]. This might be a contributing factor to the relatively lower iron concentration accompanied by high zinc concentration in the cultivated (pond) shrimps. Although the order of lead accumulation was preserved shrimp $>$ pond shrimp > freshwater shrimps, the concentrations in all the shrimp categories were lower than the established limit set by FAO (Fig. 3).

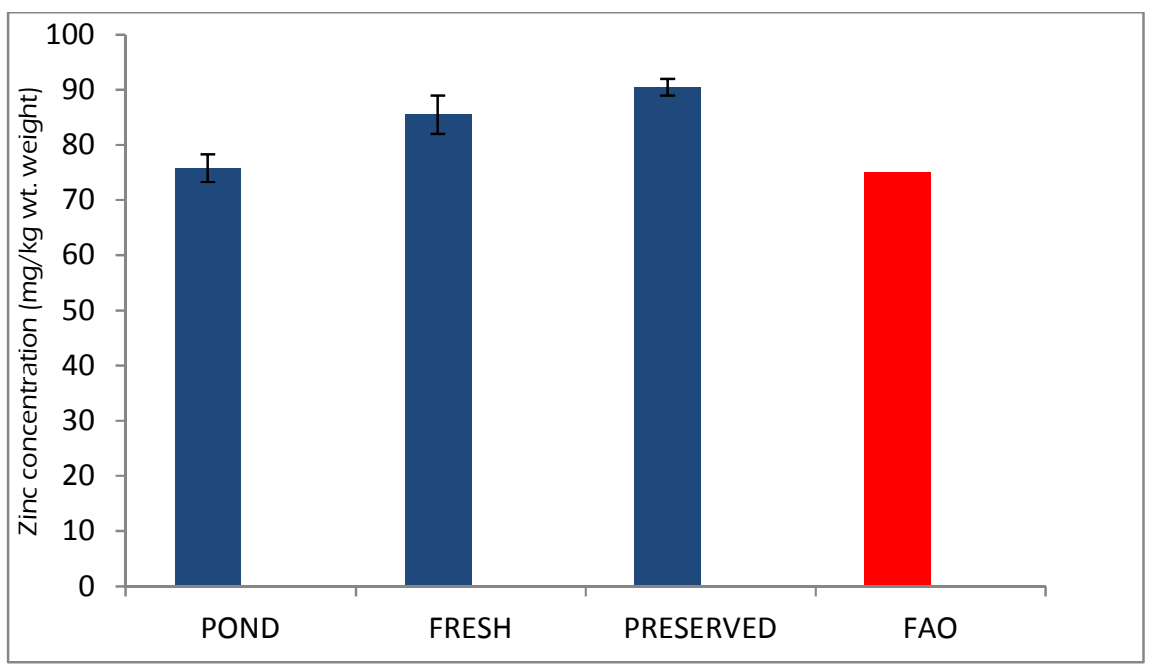

Fig. 3. Concentrations of zinc in different shrimp categories $N=30$, FAO limit $=75 \mathrm{Mg} / \mathrm{Kg}$ wt. weight [22] 


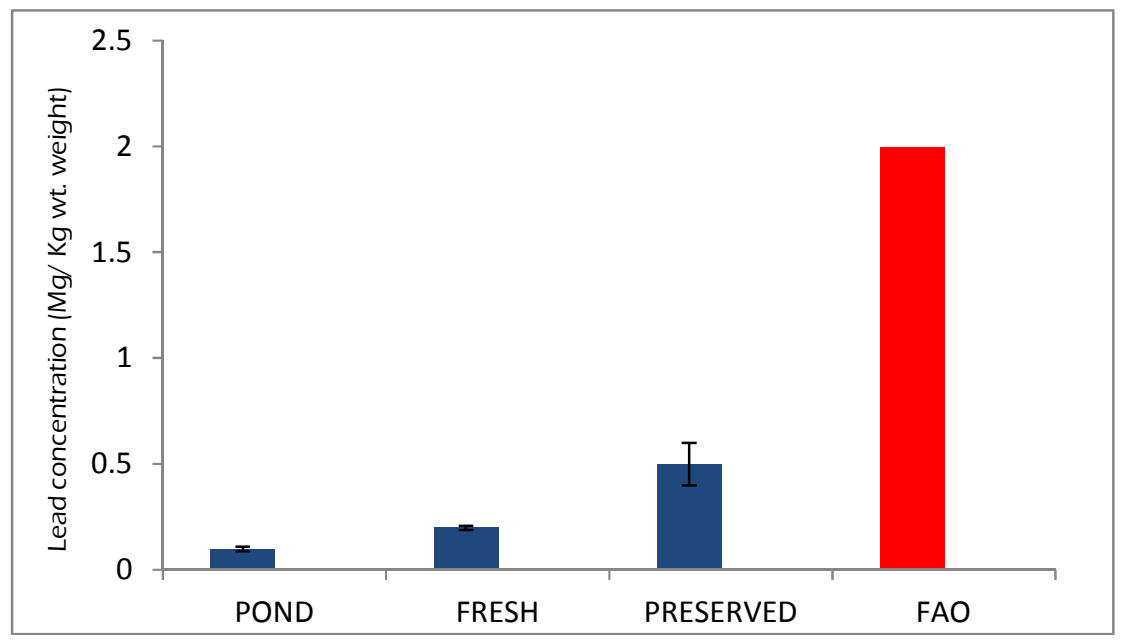

Fig. 4. Concentrations of lead in different shrimp categories $\mathrm{N}=30$, FAO limit $=2 \mathrm{Mg} / \mathrm{Kg}$ wt. weight [22]

The concentrations of cadmium in all the shrimp categories were lower than the FAO regulatory limit. Cadmium like any other substance could be absorbed via the gills and has been known to cause damage to shrimp gills. Cd poisoning could lead to anemia, renal damage, bone disorder and cancer of the lungs. The highest concentration of cadmium was $0.4 \mathrm{mg} / \mathrm{kg}$ in the freshwater shrimp and the lowest concentration $(0.09 \mathrm{Mg} / \mathrm{Kg}$ ) was observed in pond (cultivated) shrimp (Fig. 5).

Nickel concentration detected in the tissues of all shrimp categories were lower than the regulatory limit established by FAO (Fig. 6). Low concentrations of nickel accompanied by high concentrations of iron were earlier observed in Clarias gariepinus and Tilapia mariae of Osse River, Nigeria by Isibor and Imoobe [8]. This is can be attributed to the high essentiality of iron as a constituent of haemoglobin and nonessentiality of nickel.

Heavy metals with concentrations which were observed to be higher than their recommended values were further subjected to health risk assessments. The preserved shrimps followed by the freshwater shrimps had health risk indices of iron (Fig. 7), manganese (Fig. 8), and zinc (Fig. 9), while the health risk of

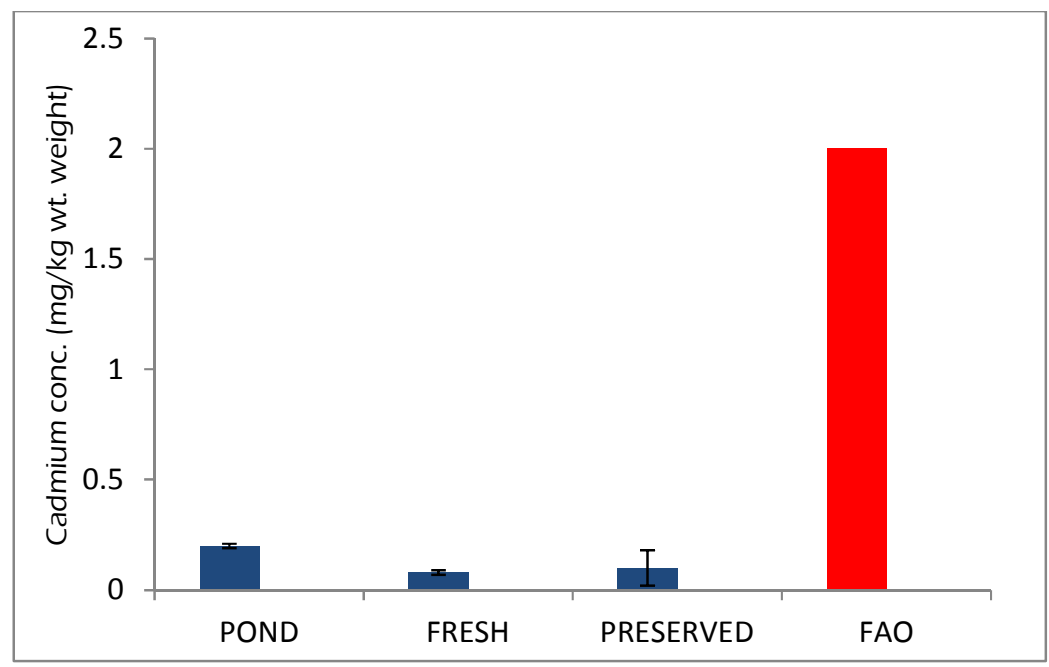

Fig. 5. Concentrations of cadmium in different shrimp categories $\mathrm{N}=30$, FAO limit= $2 \mathrm{Mg} / \mathrm{Kg}$ wt. weight [21] 


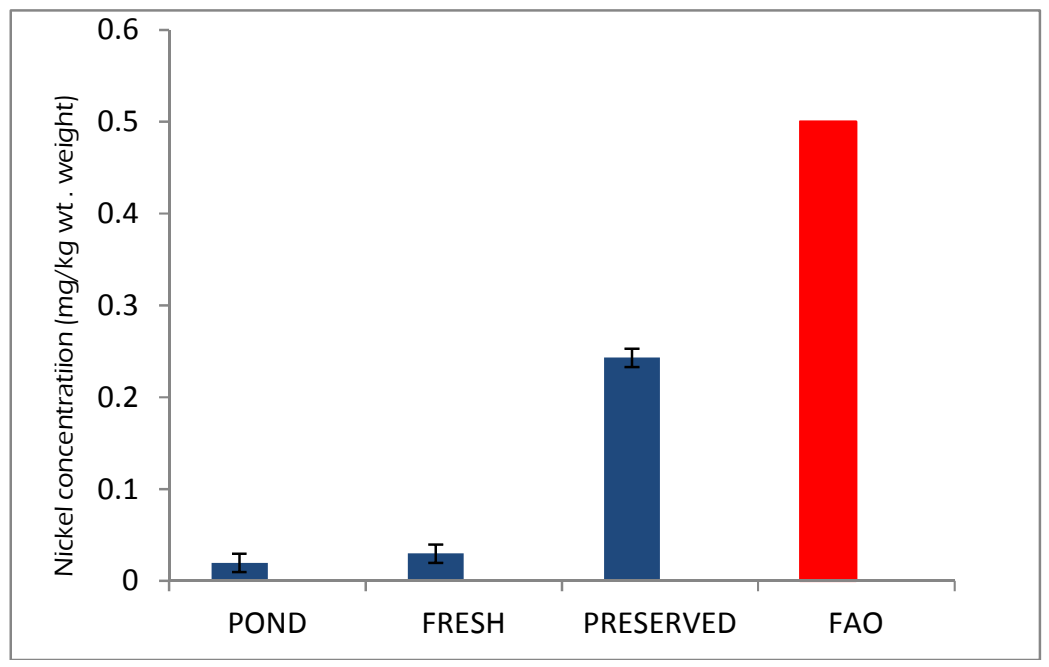

Fig. 6. Concentrations of nickel in different shrimp categories $N=30, F A O$ limit $=0.5 \mathrm{Mg} / \mathrm{Kg}$ wt. weight [22]

zinc recorded in the pond shrimp was exactly on the margin line of significance (Fig. 9). This implies that preserved shrimps posed the highest risks to the consumers. This can be attributed to the chemicals used in preserving the shrimps. The significant health risk index of iron observed in the freshwater shrimps can be attributed to the oil exploration activities around Ekpan Creek.

Generally, the contaminants in the observed shrimps were mainly essential metals. This is partly due to their high thresholds of essentiality. The orders of health risks among the metals detected in the preserved shrimps was $\mathrm{Zn}>\mathrm{Fe}>$
$\mathrm{Mn}, \mathrm{Mn}>\mathrm{Zn}>\mathrm{Fe}$, and $\mathrm{Mn}>\mathrm{Fe}>\mathrm{Zn}$ in the preserved shrimps, freshwater shrimps and pond shrimps respectively. Manganese was the major contaminant in the freshwater and preserved shrimp samples. It is therefore paramount to ensure the shrimps from the ponds and the shrimp industries are carefully screened for manganese concentrations in order to prevent health implications such as poor cognitive performance in school children and neurological disorders similar to Parkinson's disease [35].

The level of manganese, zinc, and nickel detected in the blood of the individuals who consumed preserved shrimps were quite higher

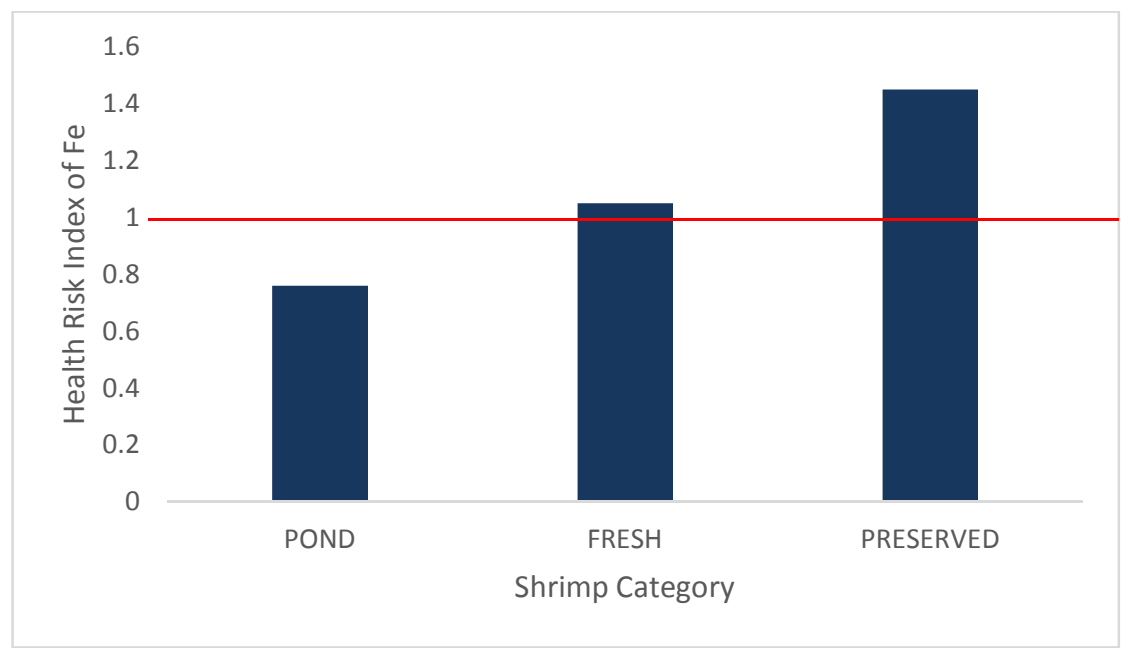

Fig 7. Health risk indices of iron in different categories of tiger shrimps. The red line indicates significant health risks at value 1 


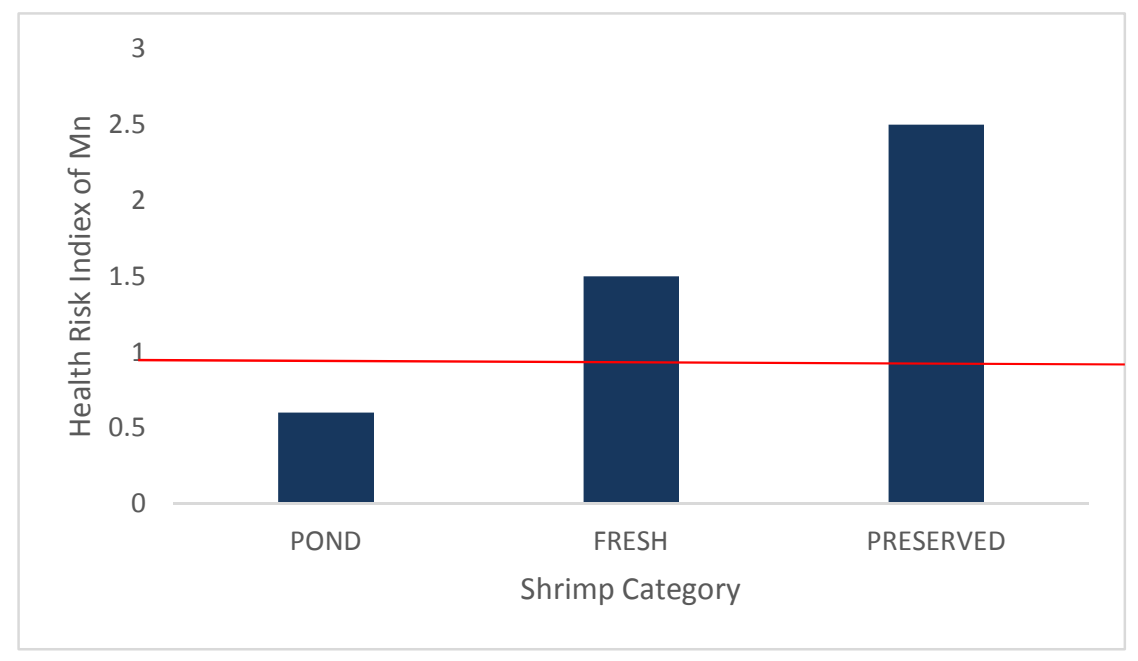

Fig. 8. Health risk indices of manganese in different categories of tiger shrimps. The red line indicates significant health risks at value 1

than the recommended limits (Table 1). The concentration of zinc in the blood of the individuals who consume freshwater shrimps were also higher than the recommended limit. This observation is backed up by the results of the sequence and health risks of both metals, except in the case of nickel which had no significant health risk. The unexpectedly high concentration of nickel in the blood of the consumers of the preserved shrimp might be due to a high octanol-water partition coefficient of nickel in the consumers. It is important for shrimpers to have substantial knowledge about the environmental conditions the shrimps were exposed to in the wild prior to capture, so as to incorporate the information in decision making in terms of preservation options.

The levels of metals detected in the blood of the consumers of the respective shrimps quite conform to the observations of the concentrations in the tissues of the shrimps. This implies that shrimp consumption had corresponding impacts on the health of the consumers. Results suggest careful screening of shrimps (particularly processed ones) for concentrations of heavy metals before approval by authorities. Use of chemicals such as sodium bisulfate, tripolyphosphate etc. is therefore discouraged.

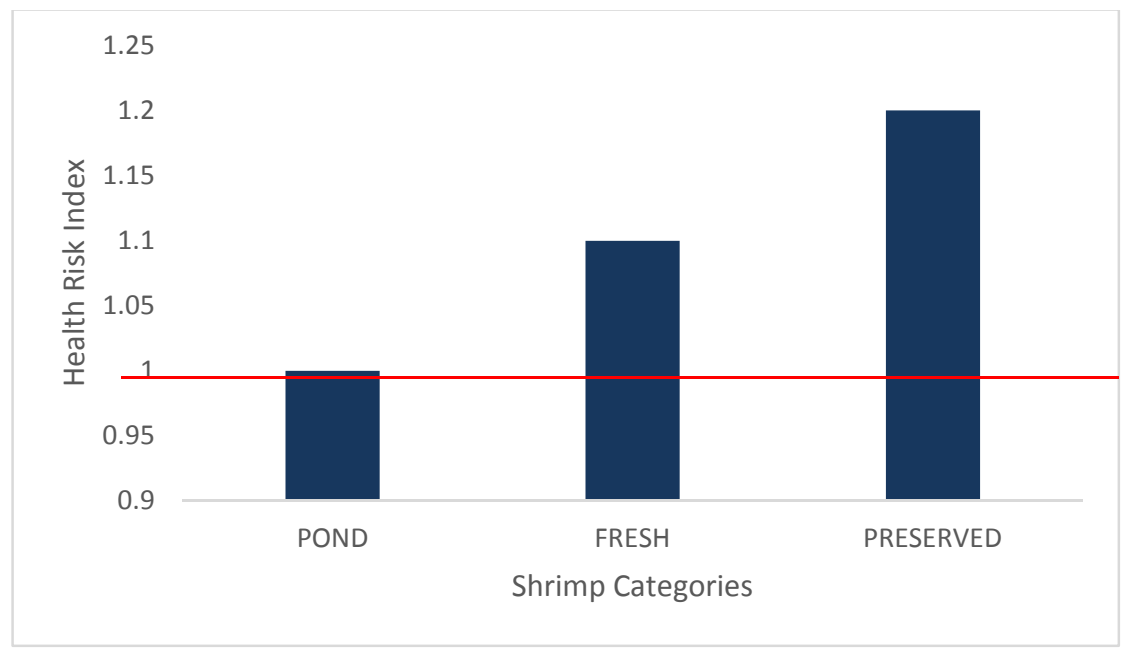

Fig. 9. Health risk indices of zinc in different categories of tiger shrimps. The red line indicates significant health risks at value 1 
Table 1. Comparison of heavy metals $(\mu \mathrm{g} / \mathrm{L})$ in consumers of Pond, River, and Frozen Shrimp with a Reference standard

\begin{tabular}{|c|c|c|c|c|c|c|}
\hline Blood category & $\mathbf{F e}$ & $\mathbf{M n}$ & $\mathrm{Zn}$ & $\mathbf{P b}$ & Cd & $\mathrm{Ni}$ \\
\hline Pond shrimp & $311.5 \pm 12$ & $11.42 \pm 0.04$ & $2864.68 \pm 122.72$ & $6.31 \pm 0.001$ & $0.9 \pm 0.08$ & $0.12 \pm 0.26$ \\
\hline Freshwater shrimp & $511.2 \pm 4$ & $15.2 \pm 0.02$ & $9064.8 \pm 12.2^{x}$ & $10.8 \pm 0.01$ & $4.5 \pm 0.2$ & $0.1 \pm 0.63$ \\
\hline Preserved shrimp & $452.2 \pm 16$ & $24.2 \pm 2^{\pi}$ & $8864.68 \pm 98.72 *$ & $14.2 \pm 0.01$ & $3.8 \pm 0.01$ & $0.3 \pm 0.01^{\pi}$ \\
\hline $\begin{array}{l}\text { Certified Range } \\
\text { [39] }\end{array}$ & $309-521$ & 8-18.7 & $4400-8600$ & $8-18.7$ & $0.3-7$ & 0.2 \\
\hline
\end{tabular}

\section{CONCLUSION}

The shrimps exhibited different trends of heavy metals according to their sources. Results showed that the safety in consumption of the shrimps was in the order of cultivate (pond) shrimps > freshwater shrimps > preserved shrimps. Choice of construction materials for shrimp pond should be well informed and stringent water quality monitoring is recommended in Tiger shrimp aquaculture while incorporating adoption of environment friendly agricultural practices. Perturbed aquatic environments such as Ekpan Creek require protection from anthropogenic activities and impactful remediation process so as to protect native Tiger shrimps and other aquatic biota.

\section{ACKNOWLEDGEMENT}

Without reservations, we profoundly appreciate the unparalleled financial support rendered by the Covenant University Centre for Research and Innovation and Discovery (CUCRID).

\section{COMPETING INTERESTS}

Authors have declared that no competing interests exist.

\section{REFERENCES}

1. Isibor PO, Igbinovia JO, Aworunse OS, Taiwo OS, Ige OJ. Application of antioxidant enzymes as biomarkers in cultivability assessment of palaemonid shrimps. Annual Research and Review in Biology. 2017;16(6):1-18.

2. Ibrahim HM, Salama MF, El-Banna HA. Shrimp's waste: Chemical composition, nutritional value and utilization. Molecular Nutrition and Food Research. 1999;43(6): 418-423.

3. Cespedes A. What is the nutritional value of shrimp? 2017.
Available:www.livestrong.com/artcle/26229 6-what-is-the-nutritional-value-of-shrimp

4. Kundu GM, Alauddin M, Akter MS, Khan MS, Islam MM. Metal contamination of commercial fish feed and quality aspects of farmed tilapia (Oreochromis niloticus) in Bangladesh. Bioresearch Communications. 2017;3:345-353.

5. Sen I, Shandil A, Shrivastava V. Study for determination of heavy metals in fish species of the river Yamuna (Delhi) by inductively coupled plasma-optical emission spectroscopy (ICP-OES). Advances in Applied Science Research. 2011;2:161-166.

6. El-Moselhy KM, Othman Al, El-Azem HA, El-Metwally MEA. Bioaccumulation of heavy metals in some tissues of fish in the Red Sea, Egypt. Egyptian J. of Basic and Applied Sciences. 2014;1(2014):97-105.

7. Stancheva M, Makedonski L, Peycheva K. Determination of heavy metal concentrations of most consumed fish species from Bulgarian Black Sea coast. Bulgarian Chemical Communications. 2014;46:195-203.

8. Isibor PO, Imoobe TOT. Comparative analysis of contaminability between Clarias gariepinus and Tilapia mariae. Annual Research and Review in Biology. 2017;16(5):1-14.

9. Shovon MNH, Majumdar BC, Rahman Z. Heavy metals (Lead, Cadmium and Nickel) concentration in different organs of three commonly consumed fishes in Bangladesh. Fish Aqua J. 2017;8(3):1-5.

10. Tukura BW, Gimba CE, Ndukwe IG, Kim BC. Physicochemical characteristics of water and sediment in Mada River, Nasarawa State, Nigeria. International Journal of Environment and Bioenergy. 2012;1(3):170-178.

11. Isibor PO, Imoobe TOT, Izegaegbe JI, Oluowo EF. Assessment of some heavy metals and total hydrocarbons in Clarias gariepinus fish of Osse River, Edo State, 
Nigeria. J. Environ. Sci., Toxicol. Food Technol. 2016;10(9):144-151.

12. Ogbeibu AE, Oriabure PA, Oboh IP, Edogun IS. The effects of Brewery effluent discharge on the water quality and sediment of Ikpoba River, Benin City, Nigeria. Journal of Aquatic Sciences. 2014;29(1A):43-58.

13. Froese $\mathrm{KL}$, Verbrugge DA, Ankley GT, Niemi GJ, Larsen CP, Giesy JP. Bioaccumulation of polychlorinated biphenyls from sediments to aquatic insects and tree swallow eggs and nestlings in Saginaw Bay, Michigan, USA. Environmental Toxicology and Chemistry. 1998;17(3):484-492.

14. Davies OA, Allison ME, Uyi HS. Bioaccumulation of heavy metals in water, sediment and periwinkle (Tympanotonus fuscatus var radula) from the Elechi Creek, Niger Delta. African Journal of Biotechnology. 2006;5(10):968-973.

15. Akan JC, Salwa M, Yikala BS, Chellube ZM. Study on the distribution of heavy metals in different tissues of fishes from river Benue in Vinikilang, Adamawa State. British Journal of Applied Science \& Technology. 2012;2(4):311-333.

16. Centers for Disease Control and Prevention (CDC). Second nutritional report on biochemical indicators of diet and nutrition in the U.S. population. National Center for Environmental Health. 2012; 483.

17. Harrington JM, Young DJ, Essader AS, Summer SJ, Levine KE. Analysis of human serum and whole blood for mineral content by ICP-MS and ICP-OES: Development of a mineralomics method. Biol. Trace Elem. Res. 2014;160(1):132-142.

18. Chan TY. Shrimps and prawns. 851-971. In Carpenter, K.E. and V.H.Niem (eds). FAO species identification guide for fishery purposes. The Living Marine Resources of the Western Central Pacific. Cephalopods, Crustaceans, Holothurians and Sharks. Rome, FAO. 1998;2:687-1396.

19. World Medical Association (WMA). Declaration of Helsinki Ethical principles for medical research involving human subjects. 59th WMA General Assembly, Seoul. 2008;5.

20. Turkmen G. Seasonal variation in heavy metals in Shrimps Penaeus kerathurus (Forskal, 1775) from Izmir Bay. J. Amin. Vet. Adv. 2012;11(15):2839- 2844.
21. Van Loon JC. Analytical atomic spectroscopy. Selected methods. Academic Press, New York. 1980;337.

22. Olaifa FE, Olaifa AK, Adelaja AA, Owolabi, AG. Heavy metal contamination of Clarias gariepinus from lake and fish farm in Ibadan, Nigeria. Afr. J. Biomed. Res. 2004;7:145-148.

23. Food and Agricultural Organization (FAO). Fishery Profile: The Federal Republic of Nigeria. 2007;24.

24. Heidarieh M, Maragheh GM, Shamami MA, Behgar M, Ziaei F, Akbari Z. Evaluate of heavy metal concentration in shrimp (Penaeus semisulcatus) and crab (Portunus pelagicus) with INAA method. J. Springer Plus. 2013;2(72):1-5.

25. Das PR, Hossain MK, Sarker BS, Parvin A, Das SS. Heavy metals in farm sediments, feeds and bioaccumulation of some selected heavy metals in various tissues of farmed Pangasius hypophthalmus in Bangladesh. Fish Aqua J. 2017;8(3):1-8.

26. Isibor PO, Oluowo EF. Evaluation of some heavy metals and total petroleum hydrocarbon in water and Palaemonid Shrimps (Macrobrachium vollenhovenii) of Egbokodo River, Warri, Delta State, Nigeria. Journal of Applied Life Sciences International. 2016;6(4):1-12.

27. Mansour SA, Sidky MM. Ecotoxicological studies. 3: Heavy metals contaminating water and fish from Fayoum Governorate, Egypt. Food Chem. 2002;78: 15-22.

28. Jezierska B, Witeska M. The metal uptake and accumulation in fish living in polluted waters. Soil and Water Pollution Monitoring, Protection and Remediation. J Springer. 2006;3(69):107-114.

29. Omoigberale MO, Ikponmwosa- Eweka O. Evaluation of heavy metals of the Palaemonid Shrimps (Macrobrachium vollenhovenii) in Osse River, Nigeria. Bioscience Research Communications. 2010;22(5):247-254.

30. Javed M, Usmani N. Accumulation of heavy metals in fishes: A human health concern. International Journal of Environmental Sciences. 2011;12(2):2249-2596.

31. Manoguerra AS, Erdman AR, Booze LL, Christianson G, Wax PM, Scharman EJ. Iron ingestion: An evidence-based consensus guideline for out-of-hospital management. Clin Toxicol (Phila). 2005;43(6):553-570. 
32. Chang TP, Rangan C. Iron poisoning: A literature-based review of epidemiology, diagnosis, and management. Pediatr Emerg Care. 2011;27:978-85.

33. United States Department of Health and Human Services. Toxicological profile for manganese. Public Health Service: Agency for Toxic Substances and Diseases Registry (ATSDR). 2012;556.

34. Cousins RJ. Zinc. In: Filer LJ, Ziegler EE, editors. Present knowledge in nutrition. 7th ed. Washington DC: International Life Science Institute Nutrition Foundation. 1996;293-306.

35. Agency for Toxic Substances and Disease Registry (ATSDR). Public Health statement for zinc: Public service. Department of Health and Human Services. 2005;42.
36. Thailand B. Expert consultation on human vitamin and mineral requirements. Vitamin and Mineral Requirements in Human Nutrition: Report of Joint FAO/WHO Expert Consolation; 2nd Edition. 2004;341.

37. Hambidge M, Krebs NF. Interrelationships of key variables of human zinc homeostasis: Relevance to dietary zinc requirements. Annu Rev Nutr. 2001;21: 429-452.

38. Roohani N, Hurrell R, Kelishadi R, Schulin R. Zinc and its importance for human health: An integrative review. J Res Sci. 2013;18(2):144-157.

39. lyengar $\mathrm{V}$, Woittiez J. Trace elements in human clinical specimens: Evaluation of literature data to identify reference values. Clin Chem. 1988;34(3):474-481.

(c) 2018 Isibor et al.; This is an Open Access article distributed under the terms of the Creative Commons Attribution License (http://creativecommons.org/licenses/by/4.0), which permits unrestricted use, distribution, and reproduction in any medium, provided the original work is properly cited.

Peer-review history:

The peer review history for this paper can be accessed here: http://www.sciencedomain.org/review-history/22956 